\title{
The Correlation between Knowledge, Attitudes toward Occupational Safety and Health and Near Miss
}

\author{
Hubungan Tingkat Pengetahuan, Sikap Kesehatan dan Keselamatan Kerja dengan \\ Near Miss
}

\author{
Febrina Dewi Safitri, Noeroel Widajati \\ Department of Occupational Safety and Health, Faculty of Public Health, Universitas Airlangga \\ Campus C Mulyorejo, Surabaya, East Java 60115, Indonesia
}

\begin{abstract}
Introduction: The research result conducted by Frank Bird concluded that every Occupational Safety and Health is preceded by a near-injury occurrence or near miss. Near miss is an incidence that potentially causes loss, which is triggered by direct factors, namely unsafe action, unsafe conditions, and basic factors, such as workers and works. Workers as a basic factor comprise their knowledge and attitudes towards Occupational Safety and Health-related to Personal Protective Equipment (PPE). Methods: This research is descriptive research that aims to identify the strength of the relationship between the knowledge and attitudes toward Occupational Safety and Health-related to PPE toward near miss in the Outfitting Unit at PT Dok dan Perkapalan Surabaya by applying the cross-sectional design. The data was obtained by questionnaire and interview. In addition, the questionnaire was distributed to all 30 workers in the Outfitting Unit at PT Dok dan Perkapalan Surabaya. Results: Indicated that the majority of the workers experienced a low-level of near-miss (90\%), while the other $10 \%$ experienced a moderate-level of near-miss. The correlation coefficient value as many as 0.149 denoted that there was a weak correlation between the workers' knowledge of Occupational Safety and Health and a near miss. Similarly, the relationship between the workers' attitudes toward occupational safety and health regarding PPE and near-miss is also a weak relationship with the correlation coefficient value of 0.236 . Conclusion: It is affirmed that effective communication between units and the provision of PPE are the factors that cause near-miss incidence in the company.
\end{abstract}

Keywords: attitude, knowledge, near miss

\section{ABSTRAK}

Pendahuluan: Hasil studi Frank Bird mengatakan bahwa setiap kejadian kecelakaan akan didahului oleh kejadian nyaris cidera. Near miss yang tidak dikendalikan dapat menimbulkan kerugian terhadap pekerja, alat atau mesin kerja, lingkungan, dan reputasi perusahaan. Near missadalahkejadian yang berpotensi menimbulkan kerugian disebabkan oleh beberapa faktor penyebab langsung, antara lain unsafe action dan unsafe condition, serta factor penyebab dasar, antara lain factor pekerja dan factor pekerjaan. Faktor pekerja adalah pengetahuan dan sikap Kesehatan dan Keselamatan Kerja (K3) terkait Alat Pelindung Diri (APD). Metode: Penelitian yang digunakan adalah deskriptif untuk mengetahui kuat hubungan tingkat pendidikan K3 dan sikap K3 terkait APD dengan near miss di Unit Outfitting PT Dok dan Perkapalan Surabaya. Rancang bangun penelitian berupa cross sectional. Data diperoleh melalui hasil kuesioner dan wawancara. Kuesioner dibagikan kepada seluruh pekerja di Unit Outfitting PT Dok dan Perkapalan Surabaya, yaitu sebanyak 30 responden. Hasil: Penelitian menunjukkan bahwa mayoritas pekerja mengalami near miss dalam kategori Low (90\%) dan 10\% lainnya termasuk kategori Moderate. Tingkat keeratan hubungan antara variabel tingkat pengetahuan K3 dengan near miss sebesar 0,149 tergolong lemah dan kuat hubungan sikap K3 terkait APD dengan near miss sebesar 0,236 yang tergolong korelasi lemah. Simpulan: Terdapat faktor penyebab near miss yang diduga memiliki hubungan terhadap near miss, yaitu komunikasi efektif antar unit dan penyediaan Alat Pelindung Diri (APD).

Kata kunci: near miss, pengetahuan, sikap

Author for Correspondence:

Febrina Dewi Safitri

Email: febrinadewi27@gmail.com

Telephone: +6281357811875

(C2019 IJOSH. Open access under CC BY NC-SA license doi: 10.20473/ijosh.v8i3.2019.328-335. Received July 08, 2018, received in revised form September 06, 2018, Accepted November 04, 2019, Published: December 2019 


\section{INTRODUCTION}

Companies in Indonesia begin to pioneer the occupational safety and health controlling and protection for their workers by realizing the urgency of workers' health and safety aspects to improve the workers' welfare and productivity. Hazard controlling efforts have been carried out to minimize the risk by considering the results of the previous risk analysis. A hazardous workplace potentially leads to unexpected events or incidents. Consequently, those incidents are potentially lead to unwanted work accidents.

Pioneering the effort of Occupational Safety and Health management requires commitment. Commitment is supposed to be built from within every aspect in the company, start from the supervisor to all of their working team to always obey the rules, for instance, by wearing Personal Protective Equipment (PPE) appropriately.

Personal Protective Equipment can protect the workers from hazardous matters exposure in the work area. Awareness or attitude built among the workers aims to shape the habit of wearing PPE, depending on the workers' knowledge level so that they understand and aware of wearing PPE urgency appropriately.

Wearing PPE during working can reduce nearmiss occurrence. According to the ILCI theory, the absence of adequate PPE is considered as unsafe action that can trigger the near-miss incident. In fact, this unsafe action is direct cause of near miss while the workers' knowledge and attitudes toward Occupational Safety and Health belong in the worker's factor, which is the basic cause of nearmiss.

According to the East Cambridgeshire District Council (2017), near misses or dangerous events may cause injuries. Therefore, reporting is necessary in order to investigate the incident source. The investigation aims to identify weaknesses in the safety system, procedures, even the workers' conditions, and actions.

Similarly, University of Bristol (2016), defines near miss as an event that does not instantly cause injuries, but can potentially cause it. These events should be monitored and investigated to ensure corrective actions carried out to prevent similar accidents.

Several aspects that need to be noted in a nearmiss report according to Environmental Health and Safety (2018) are the reporter, reporting time, near-miss causes (due to unsafe action, unsafe condition or area, unsafe condition of equipment, unsafe equipment usage, etc), location of near-miss accident, applicable safety advice, and potential hazards explanation at the location. Not only the cause of the occupational accident but also the cause of near-miss accidents must be identified to prevent other occupational accidents (Health and Safety Executive, 2004).

The workers in the occupational and environmental safety and health department at PT Dok dan Perkapalan Surabaya, a shipyard company located in the West Surabaya, often experience nearmiss incidents, In fact, near-miss has the potential to cause injury, morbidity, and death (British Standards Institution, 2007).

Referring to the data, East Java is reported as the province with the highest number of occupational accidents. In 2011 alone, out of all occupational accidents in Indonesia, 9,891 of those occurred in East Java (Data and Information Center of the (Ministry of Health Data and Information Center, 2015).

The difference between an accident and nearmiss according to the Pennsylvania Training for Health and Safety (2012) ) is that there are no losses caused by near-miss events, while accidents cause losses. Those losses may have an impact on workers, company assets, environment, and company reputation. However, both accidents and near-miss events must be reported to prevent a similar occurrence in the future.

According to Mbuvi, Kinyua and Mugambi (2015), a near miss is an unplanned event that does not cause injury, pain, or damage but potentially causing it. Nonetheless, there are positive and negative sides of near-miss accidents. The positive aspect includes the improvement opportunities for the company. In this case, the improvements can be in the form of the working environment, the workers' safety and health, and the existed occupational safety and health system.

In addition, the research conducted by stated that the most crucial aspect in any occupational safety program is the reported near-miss incidents because it leads to the identification, investigation, and improvement of the problems before occupational accidents actually happen.. According to Rizky (2003), one of the basic events that lead to the accident is the lack of knowledge.

Thus, based on the background elucidated beforehand, the research aims to identify the 
correlation between the knowledge and the attitudes toward Occupational Safety and Health and nearmiss in the Outfitting Unit at PT Dok dan Perkapalan Surabaya.

\section{METHODS}

This research was descriptive research that applied a cross-sectional design. This research was conducted in the shipbuilding and repair industry in Surabaya, namely PT Dok dan Perkapalan Surabaya or commonly referred to as PT DPS. The output generated in the Outfitting Unit is ship interior, such as shelves, tables, chairs, doors, pipes, and windows. The work stages carried out in the unit include welding, sandblasting, and painting. The study was conducted at the riskiest work stage which was at the sandblasting stage.

The population of this research was 30 workers in the Outfitting Unit. Moreover, this research applied total populated sampling, so it did not apply a calculation in determining the research sample size and method. The independent variable was the workers' knowledge level of occupational safety and health and their attitudes toward occupational safety and health correlated with PPE, while the dependent variable was near miss.

The data employed in this research was the primary data collected through questionnaires on the knowledge level and the attitudes toward occupational safety and health related to PPE.

The research was conducted from January to February 2018. The questionnaires were collected during the break time at around 11:15 to 13:00 WIB. The data presentation techniques employed were coding, checking, entry, and data analysis. The coding was carried out to put the data easily, then continued with checking the data obtained, starting from the questionnaire fulfillment completeness and the respondents' answer clarity, followed by entering the data into the data processing software.

Afterward, the research data obtained were then analyzed by using statistical calculations through data processing software. Univariate and bivariate analyses were implemented to analyze the data. Univariate analysis is a statistical analysis applied to find out the knowledge level distribution of occupational safety and health, attitudes toward occupational safety and health, and near-miss. The results of the analysis were employed to identify the strength of the relationship between the variables experienced by the workers in the Outfitting Unit.

\section{RESULTS}

The research results were in the form of the answer to the questionnaire distributed to 30 respondents. The respondents were reported working as sandblasters, painters, welders, and plat cutting workers in the company.

\section{Univariate Analysis}

\section{Knowledge Level of Occupational Safety and Health}

Table 1 explains that almost all of the workers in the Outfitting Unit had a high knowledge level, amounting to $83.3 \%$ or 25 out of 30 people. Additionally, none of the workers had a low knowledge level of occupational safety and healthrelated to PPE.

\section{Attitudes toward Occupational Safety and Health}

Based on the results of the univariate analysis regarding the attitudes toward Occupational Safety and Health, it is concluded that none of the workers had negative attitudes toward the wearing of PPE. In addition, the majority of the workers had a positive attitude, that is, as many as 20 workers, while the other 10 workers belong to the neutral category of attitudes.

Table 1.The Distribution of the Workers' Knowledge Level of Occupational Safety and Health related to PPE in the Outfitting Unit at PT Dok dan Perkapalan Surabaya in 2018

\begin{tabular}{ccc}
\hline Knowledge Level & Frequency (n) & Percentage (\%) \\
\hline Low & 0 & 0 \\
Moderate & 5 & 16.7 \\
High & 25 & 83.3 \\
\hline Total & 30 & 100 \\
\hline
\end{tabular}

Table 2. The Distribution of Workers' Attitudes toward Occupational Safety and Health related to EPP in the Outfitting Unit at PT Dok dan Perkapalan Surabaya in 2018

\begin{tabular}{ccc}
\hline Attitudes & Frequency (n) & Percentage (\%) \\
\hline Negative & 0 & 0 \\
Neutral & 10 & 33.3 \\
Positive & 20 & 66.7 \\
\hline Total & 30 & 100 \\
\hline
\end{tabular}




\section{Near Miss}

Table 3 indicates that near-miss incidents experienced by the workers in the Outfitting Unit were mostly considered as the incidents in the low category, which is as much as $90 \%$ or 27 out of 30 workers. Meanwhile, none of the workers encountered near-miss accidents considered a high category $(0 \%)$.

\section{Bivariate Analysis}

\section{Knowledge Level of Occupational Safety and Health related to $P P E$}

As seen in Table 4, the workers who encountered low category of near-miss accidents were those who had a high knowledge level of Occupational Safety and Health related to PPE $(76.7 \%)$. On the other hand, the workers who had the lowest percentage of encountering near miss were the workers who had moderate knowledge level of occupational safety and health $(3.3 \%)$.

\section{Attitudes toward Occupational Safety and Health related to PPE}

Based on Table 5, most of the workers encountering low category of near-miss accidents

Table 3. The Distribution of Near Miss Incidents Experienced by the Workers in the Outfitting Unit at PT Dok dan Perkapalan Surabaya in 2018

\begin{tabular}{ccc}
\hline Near Miss & Frequency (n) & Percentage (\%) \\
\hline Low & 27 & 90 \\
Moderate & 3 & 10 \\
High & 0 & 0 \\
\hline Total & 30 & 100 \\
\hline
\end{tabular}

Table 4. Cross-tabulation between the Knowledge Level of Occupational Safety and Health and Near Miss in the Outfitting Unit at PT. Dok dan Perkapalan Surabaya in 2018

\begin{tabular}{ccccccccc}
\hline \multirow{2}{*}{$\begin{array}{c}\text { Knowledge } \\
\text { Level }\end{array}$} & \multicolumn{9}{c}{ Low } & \multicolumn{3}{c}{ Moderate } & \multicolumn{2}{c}{ High } & \multirow{2}{*}{ Total } \\
\cline { 2 - 7 } & $\mathbf{n}$ & $\%$ & $\mathbf{n}$ & $\%$ & $\mathbf{n}$ & $\%$ & $\mathbf{n}$ & $\%$ \\
\hline Low & 0 & 0 & 0 & 0 & 0 & 0 & 0 & 0 \\
Moderate & 4 & 13.3 & 1 & 3.3 & 0 & 0 & 5 & 16.7 \\
High & 23 & 76.7 & 2 & 6.7 & 0 & 0 & 25 & 86.7 \\
\hline Total & 27 & 90 & 3 & 10 & 0 & 0 & 30 & 100 \\
\hline
\end{tabular}

were the workers who had a high level of attitude toward Occupational Safety and Health as much as $63.3 \%$ or 19 workers. Meanwhile, there was only one worker encountering moderate category of a near-miss accident, which was the worker who had a high attitude toward Occupational Health and Safety related to PPE, reached 3.3\%.

After implementing the cross-tabulation analysis between the knowledge level of Occupational Safety and Health and near-miss incidents, the next step performed was calculating the strength of the relationship between variables by employing the Spearman correlation test. Spearman correlation test was applied to prove the closeness of the relationship of one variable with another or independent variable with the dependent one. In addition, the Spearman test is also performed when the variable has ordinal scale data.

The results identified a strong correlation between the variable of the knowledge level of Occupational Safety and Health related to PPE and the variable of near-miss with the correlation coefficient value of as much as 0.149 . Other than that, there was also a correlation between attitudes toward Occupational Safety and Health variable

Table 5. Cross-tabulation between the Attitudes toward Occupational Safety and Health and Near Miss in the Outfitting Unit at PT Dok dan Perkapalan Surabaya in 2018

\begin{tabular}{ccccccccc}
\hline \multirow{3}{*}{ Attitude } & \multicolumn{9}{c}{ Near Miss } & \multirow{2}{*}{ Total } \\
\cline { 2 - 7 } & \multicolumn{2}{c}{ Low } & \multicolumn{3}{c}{ Moderate } & \multicolumn{2}{c}{ High } & \\
\cline { 2 - 7 } & $\mathbf{n}$ & $\mathbf{\%}$ & $\mathbf{n}$ & $\mathbf{\%}$ & $\mathbf{n}$ & $\mathbf{\%}$ & $\mathbf{n}$ & $\mathbf{\%}$ \\
\hline Negative & 0 & 0 & 0 & 0 & 0 & 0 & 0 & 0 \\
Neutral & 8 & 26.7 & 2 & 6.7 & 0 & 0 & 10 & 33.3 \\
Positive & 19 & 63.3 & 1 & 3.3 & 0 & 0 & 20 & 66.7 \\
\hline Total & 27 & 90 & 3 & 10 & 0 & 0 & 30 & 100 \\
\hline
\end{tabular}

Table 6. Category of the Closeness Level of Correlation

\begin{tabular}{cc}
\hline Correlation Value & Interpretation \\
\hline 0.00 & No correlation \\
$0.01-0.09$ & Slightly weak correlation \\
$0.10-0.29$ & weak correlation \\
$0.30-0.49$ & Moderate correlation \\
$0.50-0.69$ & Strong correlation \\
$0.70-0.89$ & Very strong correlation \\
$>0.90$ & Nearly perfect correlation \\
\hline
\end{tabular}

Source: D.A. de Vaus (2002) 


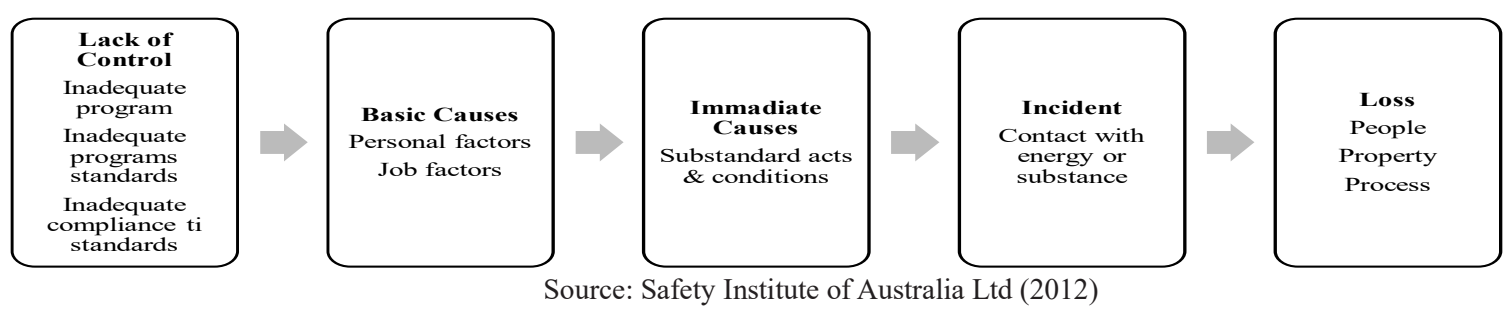

Figure 1. Five factors of Bird and Germain's

and near-miss variable which correlation coefficient value was 0.236 . The correlation obtained was classified based on the category illustrated in table 6.

Based on table 6 , the strength of the correlation between the variable of the knowledge level of Occupational Safety and Health and near-miss was as much as 0.149 , which was classified as a weak correlation. Closeness correlation level between the attitudes toward Occupational Safety and Health and near-miss accidents in the Outfitting Unit reached 0.236 , which was also classified as a weak correlation.

\section{DISCUSSION}

There are various of the works performed in the Outfitting Unit that lead to different PPE. For example, in sandblasting, the sandblaster must wear the safety face shield and helmet along with hearing protection, as well as the oxygen tube/mask to breathe while working. The PPE that the workers must wear in the Outfitting Unit consists of safety helmet, safety shoes, gloves, wear pack or coverall, mask, and face shield, especially for those who work on sandblasting and welding.

Personal Protective Equipment (PPE) is an important equipment for the workers or the people in the workplace area, whether they are doing fieldwork practice, internship, or visiting. Safety helmet covers the workers' heads from a collision, while coverall protects the whole body from particular exposure, such as chemical matters and dust. Similarly, safety shoes help to cover the workers' feet from tripping, falling materials, and particular exposure.

Accordingly, PPE decreases the possibility of near-miss accidents. For instance, wearing proper safety shoes can minimize the slipping incident. In addition, hearing protection, such as earplugs or earmuffs, helps the workers avoid the deafening possibility. Thus, wearing PPE recklessly can be the factors of the near-miss incident, for example wearing a helmet in an inappropriate way that may cause the helmet to fall and result in tripping.

The awareness of the workers to wear PPE properly starts from the awareness to protect themselves from potential danger that can hurt them. It is necessary to get support from the company by putting the facilities in the form of PPE to build the attitude of wearing appropriate PPE while working.

The workers' factors consist of knowledge and attitude. ILCI theory stated that the workers' factor is one of the potential accident sources to occur. Other than that, there is another factor that potentially causes accidents, namely work factors, which consist of tools condition, working machine, and the working environment, for instance, physical, chemical, biological, and social environments. In addition, the scheme of how near-miss accidents occur is illustrated in Figure 1.

\section{Knowledge Level of Occupational Safety and Health}

Knowledge is obtained from the process of sensing and thinking of an object which is seen, touched, felt, smelled, and heard. Thinking makes people understand and aware of the observed object. Knowledge is the result of the individuals that understand and comprehend in cognitive or affective terms (Zins, 2007).

The knowledge of Occupational Safety and Health can be obtained from training, experience, and the school learning process. The majority of the workers in the Outfitting Unit are noticed as high school graduates who already have experience in applying their abilities and skills to real work situations. In fact, it is known that vocational school graduates have special skills or specialties in particular jobs due to the focusing of learning in high school. Hence, it causes the learning process to become easier and more applicable in the workplace. 
The knowledge related to PPE is about the proper wearing of safety helmets, gloves, safety shoes, and earplugs. In accordance with the research results, it was stated that $76.7 \%$ of the workers who had a high level of knowledge of Occupational Safety and Health related to PPE experienced the low-category of near-miss incidents. The effect of the high knowledge level of Occupational Safety and Health is regarded as a support of the campaign of wearing the PPE properly.

The Spearman correlation test results disclosed a weak correlation between the variable of the knowledge level of Occupational Safety and Health related to PPE and near miss. Apparently, it was caused by the presence of other factors that were more influential in the near-miss incidence.

There are other independent variables that have a correlation with the near-miss incidence. According to the Health and Safety Executive (2007), accidents and near-miss at work happen due to communication problems. In other words, effective communication contributes to a huge factor in the near-miss occurrence.

The effective communication meant is the communication occurs within the work units or departments, such as production units that discuss work shift, company policies, or less effective work procedures that may trigger problems or errors in working processes that result in a near miss.

Communication is an attempt to convey the messages from the communicator to the communicant that allows for feedback as a form of reciprocity. In addition, effective communication is an important factor to resolve problems or conflicts in order to build a good relationship. Furthermore, according to the National Interagency Fire Center, there is a way to build effective communication. One example is two-way communication, which depends on the communicator or communicant by considering the strengths and weaknesses of the communicator/communicant. Overall, the purpose of communication is to comprehend and understand each other's messages. The communicant or communicator attempts to provide proper feedback and an active listener.

Various factors may affect the communication effectiveness, such as the type of media used, verbal and non-verbal communication, and noise or the presence of disturbances in other communications. Building effective communication regarding Occupational safety and health between the superiors to subordinates can form a good understanding for workers related to risks and hazards of work, time span, work goals, vision, and mission of corporate, unsafe actions, and unsafe conditions.

Those understandings form the desire and awareness of working safely and healthily as the efforts to reduce unsafe actions that lead to the decrease of near-miss accidents. Thus, the workers are capable of working more productively along with obtaining better economic conditions. In addition, the PPE availability supports the awareness of the workers to wear it to create a safer workplace and to minimize near-miss incidents.

Moreover, another variable that becomes the source of the near-miss incident, according to Nik Mahdi et al. (2014), is sleep disturbance, which was investigated in an article entitled "Risk Factors for Near Miss Incident among Long-Distance Bus Drivers in Malaysia. People with sleep disorders have a low quality of sleep and unhealthy condition. Workers who experience sleep disorders can easily lose concentration at work. They feel tired and sleepy faster due to reduced and irregular sleeping hours.

Some of the characteristics of sleep disturbance, according to the Directorate of Health Promotion and Community Empowerment (2017), are loss of focus and concentration, an increase of stress, older skin looks, poor memory, and bad condition of health. The tired and drowsy workers increase the occurrence of a near-miss accident because it is considered as unsafe actions. For example, the workers can trip and fall in the workplace due to loss of concentration.

Similarly, workers who get a lack of sleep may experience frequent disremembering. It has the potential of near-miss injuries, for instance, workers who put the material carelessly can harm the other workers, such as tripping, colliding, etc.

\section{Attitudes toward Occupational Safety and Health}

Attitude is passive responses of individuals, whether negative or positive, even agree or disagree with a particular object of thought. The object of thought is obtained from the individual's sensing results. The research about the attitudes toward Occupational Safety and Health related to PPE focuses on the wearing of PPE, whether it bothers the work process or not, the response of agree or disagree with regard to the company's obligations in providing PPE, the need for procurement of 
sanctions for workers who do not wear PPE, the importance of using PPE, the exact time of wearing and storing PPE, and the compatibility of PPE used with the applicable standards or procedures.

The Spearman correlation test indicated a weak correlation between variables of the knowledge level of Occupational Safety and Health related to PPE and near miss. The research conducted by Pratiwi (2003) disclosed that there was a correlation between PPE provision and near-miss ( $\mathrm{p}$-value $=0.032$ )

Based on the definitions in the Health and Safety Executive (2013), PPE is defined as protection for workers against Occupational Safety and Health risks in the workplace. Facilities that are provided by the company support the campaign of the workers' attitude to put their safety into first priority. If the company provides PPE, the workers can easily wear it before performing the work.

The company's obligation to provide PPE for the workers, visitors, and interns of the company have been stipulated in the Law of the Republic of Indonesia Number 1 of 1970 (1970), so as with the workers' obligations to wear PPE when working. Workers who do not wear PPE are more likely to experience an accident or near-miss because the worker's body is not protected. These matters are classified as unsafe actions that have the potential for a near miss.

\section{Near Miss}

Referring to Occupational Health and Safety Assessment Series (2007), events that have the potential to cause injury, illness, and death are referred to as near miss or close call. Meanwhile, according to Pertamina Hulu Energi West Madura Offshore (2017), near-miss is defined as an unexpected event that has a potential loss. Every near-miss that occurs must be reported to Quality Health, Safety, Security, and Environment (QHSSE) to prevent ongoing incidents by workers and contractors that work at PHE WMO within a maximum of 2 hours after the event. In other words, a near miss is an event that has the potential to cause serious consequences (Dundalk Institute of Technology, 2012).

Bestowing to Phimister et al. (2003), there are seven stages of near-miss investigation, namely identification, reporting, priority and distribution, source analysis, solution identification, dissemination, and resolution.

In this research, near-miss incidents were scrutinized as the dependent variable. The identified variables of near-miss were the incident of near injury and pain the workers experienced, including the workers' intensity in violating work procedures, using damaged tools or machines, working without proper procedure to get faster result, their ignorance of incident in the workplace, and probability of avoiding harmful incident in the workplace. The latest covered tripping over material across the work area, almost falling from a top floor, working in tired and sleepy condition, and losing the concentration at work.

The majority of the workers in the Outfitting Unit at PT Dok dan Perkapalan Surabaya experienced low category of near-miss, which means the intensity of near-miss incidents rarely occurred or not often. According to the unit manager, a work that has a high intensity of near-miss is sandblasting. Sandblasting is carried out outside or in the workshop, precisely on the sea alongside the ship that needs cleansing from contamination, such as corrosion/rust and peeling paint.

The sandblasters can experience risky incidents, such as slipping and falling into the sea. It will be hard to help them if there is no supervisor or the Health, Safety, Security, and Environment (HSSE) officers. In addition to the risk of slipping, sandblasting workers are also at risk of occupational diseases, for instance, from exposure to abrasive dust used as sandblast material that may cause silicosis or other lung diseases, depending on the type of the dust or sand itself.

Near miss incident has the potential of accident in the workplace. It leads to unsafe conditions or unsafe actions. The role of the company is crucial to improve and develop knowledge and attitudes, even the actions of the workers at work related to Occupational Safety and Health.

The workers who have realized, understood, and comprehended the importance of health and safety in the workplace would avoid the conditions that have the potential to cause harm. They will do the preventive actions, such as wearing PPE, keeping the focus and concentration while at work, doing the maintenance of the tools and machines periodically, avoid smoking in the workplace, and always being careful.

\section{CONCLUSION}

There are several working departments in PT Dok dan Perkapalan Surabaya, for instance, sandblasting, painting, and welding. The research 
results indicated that the correlation between the knowledge level of Occupational Safety and Health and the near-miss incident was as much as 0.149 and was classified as a weak correlation. In addition, another factor of the near-miss incident was ineffective communication among the workers.

From the results of the Spearman correlation test, the correlation coefficient value between the attitudes toward Occupational Safety and Health and near-miss was as much as 0.236 , which was noticed as a weak correlation. Moreover, there was a factor affecting the result of the test, namely the provision of PPE. In fact, the Outfitting Unit worker majority experiences low near-miss incident even though there were still several workers who experience a moderate category.

\section{ACKNOWLEDGMENT}

The authors are grateful for God Almighty. Also, the authors would like to acknowledge the supervisor of this research and the respondents who gave their consent to participate in this research.

\section{REFERENCES}

British Standards Institution (2007) OHSAS 18001: 2007 Occupational Health And Safety Management Systems - Requirements. London:British Standards Institution.

Directorate of Health Promotion and Community Empowerment (2017) 'Kebutuhan Tidur Sesuai Usia'. Jakarta: Ministry of Health of the Republic of Indonesia.

Dundalk Institute of Technology (2012) 'Accident, Incident, Near Miss and Dangerous Occurrence Reporting Procedures'. Dundalk: Dundalk Institute of Technology.

East Cambridgeshire District Council (2017) Accident/ Near Miss Reporting Policy. Nutholt Ln: East Cambridgeshire District Council.

Environmental Health and Safety (2018) 'NearMiss Report Form'. Oklahoma: Oklahoma State University.

Health and Safety Executive (2004) Investigating Accidents and Incidents. London: Health and Safety Executive.

Health and Safety Executive (2007) Reducing Error and Influencing Behaviour. London: Health and Safety Executive.
Health and Safety Executive (2013) Personal Protective Equipment (PPE) at Work. London: Health and Safety Executive.

Law of the Republic of Indonesia Number 1 of 1970 (1970) Concerning Occupational Safety. Jakarta: President of Republic of Indonesia.

Mbuvi, I. M., Kinyua, R. and Mugambi, F. (2015) 'Near Miss Incident Management, the Root for an Effective Workplace Safety is determined by the Management Commitment', International Journal of Scientific and Research Publications, 5(10), pp. 1-13.

Ministry of Health Data and Information Center (2015) Situasi Kesehatan Kerja. Jakarta: Ministry of Health of the Republik of Indonesia.

Nik Mahdi, N. N. R. et al. (2014) 'Risk factors for near miss incident among long distance bus drivers in Malaysia', Iranian Journal of Public Health, 43(3), pp. 117-124.

Pennsylvania Training for Health and Safety (2012) 'Near Miss'. Pennsylvania: Department of Labor and Industry Bureau of Workers' Compensation.

Pertamina Hulu Energi West Madura Offshore (2017) HSSE Handbook. 1st edn. Jakarta: PT. Pertamina Hulu Energi.

Phimister, J. R. et al. (2003) 'Near-Miss Incident Management in the Chemical Process Industry', Risk Analysis, 23(3), pp. 445-459.

Pratiwi, F. (2003) Studi Analisis Kejadian Near Miss Di Bagian Produksi 5/6 Dan Teknik 5/6 Unit Pm 5/6/9 PT. Pura Barutama Kudus. Undergraduate Thesis. Semarang: Faculty of Public Health, Universitas Diponegoro.

Rizky, R. I. (2003) Analisis Faktor Penyebab Kecelakaan Kerja Proyek Konstruksi GKM Tower Jakarta Selatan menggunakan Metode Fault Tree Analysis (FTA) dan Manajemen Pencegahan serta Penanganannya. Scientific Article. Bandung: Faculty of Civil and Environmental Engineering, Institut Teknologi Bandung.

Safety Institute of Australia Ltd (2012) Models of Causation: Safety, OHS Body of Knowledge. Victoria: Safety Institute of Australia Ltd.

University of Bristol (2016) 'Near Miss Reporting Guide'. Bristol: University of Bristol.

Zins, C. (2007) 'Conceptual Approaches for Defining Data, Information, and Knowledge', Journal of the American Society for Information Science and Technology, 58(4), pp. 479-493. 